\title{
Cloning, In Vitro Expression, and Tissue Distribution of a Human Prostaglandin Transporter cDNA (hPGT)
}

\author{
Run Lu, Naoaki Kanai, Yi Bao, and Victor L. Schuster \\ Departments of Medicine, Physiology, and Biophysics, Albert Einstein College of Medicine, Bronx, New York 10461
}

\begin{abstract}
We recently identified a cDNA in the rat that encodes a broadly expressed PG transporter (PGT). Because PGs play diverse and important roles in human health and disease, we cloned human PGT (hPGT) from an adult human kidney cDNA library. A consensus sequence $(4.0 \mathrm{~kb})$ derived from several clones, plus $3^{\prime}$ polymerase chain reaction amplification, exhibited $74 \%$ nucleic acid identity and $82 \%$ amino acid identity compared to rat PGT. When transiently expressed in HeLa cells, a full-length clone catalyzed the transport of $\mathrm{PGE}_{1}, \mathrm{PGE}_{2}, \mathrm{PGD}_{2}, \mathrm{PGF}_{2 \alpha}$ and, to a lesser degree $\mathrm{TXB}_{2}$. Northern blotting revealed mRNA transcripts of many different sizes in adult human heart, placenta, brain, lung, liver, skeletal muscle, pancreas, kidney, spleen, prostate, ovary, small intestine, and colon. hPGT mRNAs are also strongly expressed in human fetal brain, lung, liver, and kidney. The broad tissue distribution and substrate profile of hPGT suggest a role in the transport and/or metabolic clearance of PGs in diverse human tissues. (J. Clin. Invest. 1996. 98:1142-1149.) Key words: prostaglandins • carrier proteins $\bullet$ biological transport $\bullet$ molecular cloning
\end{abstract}

\section{Introduction}

PGs and TXs play ubiquitous and vital pathophysiological and therapeutic roles in human health and disease states, such as glaucoma: pregnancy, labor, delivery; and abortion: gastric protection and peptic ulcer formation; intestinal fluid secretion; liver protection and damage; airway resistance and asthma; blood pressure control; and modulation of inflammatory cells (1-15).

As charged organic anions at physiological $\mathrm{pH}(16,17)$, PGs traverse biological membranes poorly (18). Accordingly, PG transport is carrier-mediated in many diverse tissues, including the lung (19-22), choroid plexus (23-28), liver (29), anterior chamber of the eye $(23-25,30)$, vagina and uterus (31$33)$, and placenta $(34,35)$. Indeed, our laboratory recently identified rat prostaglandin transporter $(\mathrm{PGT}){ }^{1}$, the first cloned carrier known to catalyze the transport of PGE and $\mathrm{PGF}_{2 \alpha}$ (36).

Address correspondence to Victor L. Schuster, Renal Division, Ullmann 617, 1300 Morris Park Avenue, Bronx, NY 10461. Phone: 718430-3158; FAX: 718-824-2765; E-mail: schuster@aecom.yu.edu

Received for publication 5 December 1995 and accepted in revised form 21 June 1996.

1. Abbreviations used in this paper: hPGT, human PGT; oatp, organic anion transporting peptide; PGT, prostaglandin transporter.

J. Clin. Invest.

(c) The American Society for Clinical Investigation, Inc. 0021-9738/96/09/1142/08 \$2.00

Volume 98, Number 5, September 1996, 1142-1149
We have postulated three possible roles for PGT (36). First, PGT might mediate the efflux of newly-synthesized PGs from cells. Although PGs apparently do gain access to the cytoplasmic compartment (37), it is unclear whether a carrier is necessary for their subsequent efflux into the extracytoplasmic space.

Second, PGT might mediate epithelial PG transport. Vectorial PG transport occurs in many epithelia, including the liver, kidney, choroid plexus, anterior uvea, and uterus (22-24, $27,33,38,39)$. The tissue distribution of PGT mRNA expression in the rat (36) suggested that its expression might be limited to epithelia, and therefore that epithelial transport of PGs may represent its primary function.

A third possible role of PGT is that of mediating PG clearance and degradation. After their release from cells, PGs and TXs bind to nearby surface receptors, where they signal a broad array of physiological functions. Because there is no enzymatic activity in the plasma capable of oxidizing $\mathrm{PGE}_{1}$, $\mathrm{PGE}_{2}$, or $\mathrm{PGF}_{2 \alpha}$ (38), these prostanoids could potentially bind to receptors at a substantial distance from their sight of release if they were not metabolized locally. Local clearance of $\mathrm{PGE}_{1}$, $\mathrm{PGE}_{2}$, and $\mathrm{PGF}_{2 \alpha}$ occurs in a single passage through any of several vascular beds, such as the lung $(38,40,41)$. In contrast, prostacyclin $\left(\mathrm{PGI}_{2}\right)$ is not cleared, and thus circulates as a hormone $(42,43)$. The differing metabolism of these prostanoids appears to be due to differences in the selective uptake of some PGs into cells.

Of these three possibilities, we currently favor the clearance role for PGT, because $(a)$ the substrate specificity of the cloned transporter is very similar to that reported previously for PG clearance in the isolated perfused rat lung preparation $(20-22,36)$; and $(b)$ we have been unable to obtain PGT-mediated PG efflux using the Xenopus oocyte expression system (Chan, B., and V.L. Schuster, unpublished observations).

Using a rat PGT probe on Northern blots of human kidney RNA, we found evidence for the presence of a likely human PGT homologue. Accordingly, we screened a human kidney cDNA library and expressed a full-length human cDNA clone in cultured cells. We now report that both rat PGT and human PGT (hPGT) transport $\mathrm{PGD}_{2}$, as well as $\mathrm{PGE}_{1}, \mathrm{PGE}_{2}$, and $\mathrm{PGF}_{2 \alpha}$. Although hPGT has cDNA and deduced amino acid sequences similar to those of the rat, the tissue distribution of the mRNA transcripts is substantially broader, the diversity of transcripts is greater, and the affinity for $\mathrm{TXB}_{2}$ is greater. In addition, we find strong hPGT mRNA expression in the human fetus. The findings are important as a first step in understanding the transport of endogenous and synthetic PGs in humans.

\section{Methods}

Human kidney cDNA library screening. A DNA fragment, obtained from the rat PGT cDNA by cutting with the restriction endonuclease Hinc1 followed by gel purification, was labeled by the random primer method (44) with $\left[\alpha-{ }^{32} \mathrm{P}\right] \mathrm{dCTP}$, and was used to probe a human kidney cDNA library in the phage vector $\lambda \mathrm{gt} 10\left(\sim 10^{8} \mathrm{pfu} / \mathrm{ml}\right.$; Clontech, 
Palo Alto, CA), generated by mixed deoxythymidine and random hexamer oligonucleotide primers. After library plating and replicatransfer to Nytran Plus filters (Schleicher \& Schuell, Keene, NH), filters were hybridized overnight at $40^{\circ} \mathrm{C}$ with the ${ }^{32} \mathrm{P}$-labeled Hinc1 fragment in $5 \times \mathrm{SSC}, 2 \%$ blocking reagent, $0.1 \% \mathrm{~N}$-laurylsarcosine, and $0.02 \%$ SDS (Genius System, Boehringer Mannheim Biochemicals, Indianapolis, IN). Filters were washed as follows: twice with $1 \times$ SSC, $0.1 \%$ SDS at $40^{\circ} \mathrm{C}$; twice with $0.5 \times \mathrm{SSC}, 0.1 \%$ SDS at $40^{\circ} \mathrm{C}$; twice with $0.1 \times \mathrm{SSC}, 0.1 \%$ SDS at $40^{\circ} \mathrm{C}$; and twice with $1 \times \mathrm{SSC}$, $0.1 \%$ SDS at $50^{\circ} \mathrm{C}$. Filters were exposed overnight to X-Omat AR film at $-70^{\circ} \mathrm{C}$ (Eastman Kodak Co., Rochester, NY). Positive plaques on duplicate filters were picked for secondary screening using the same hybridization and washing conditions. Of 800,000 colonies screened, seven positive clones were isolated and subcloned into the plasmid pSPORT-1 (Gibco BRL, Gaithersburg, MD).

DNA sequencing, restriction analysis, and computer analysis. All seven positive clones were subjected to restriction mapping. Using the dideoxy chain termination method (Sequenase version 2.0 DNA sequencing kit; U.S. Biochemical Corp., Cleveland, OH), all of both strands of clone 3 and parts of the other clones were sequenced by primer walking. In addition, parts of clones 5, 7, 9, and 10 were also sequenced. The data were aligned and analyzed by MacVector (Eastman Kodak Co., Rochester, N.Y.) and GeneWorks (Intelligenetics, Inc., Campbell, CA) software programs.

3 ' rapid amplification of $c D N A$ ends $(R A C E)$ by PCR. First strand cDNA was reverse-transcribed from human kidney poly-A (+) RNA $(0.5 \mu \mathrm{g}$; Clontech) using a Not1 primer-adapter (SuperScript Plasmid System, Gibco-BRL). The initial gene-specific 18-mer primer, generated from the region 3260-3277 of clone 3, and the Not1 primeradapter were used in a first round of PCR. The initial denaturation at $94^{\circ}$ for $1.5 \mathrm{~min}$ was followed by 20 cycles of denaturation at $94^{\circ}$ for 30 $\mathrm{s}$, annealing at $50^{\circ}$ for $30 \mathrm{~s}$, and extension at $72^{\circ}$ for $1.5 \mathrm{~min}$. A final extension at $72^{\circ} \mathrm{C}$ was performed for $10 \mathrm{~min} .1 \mu \mathrm{l}$ of this product mixture was diluted into a second $50-\mu 1$ reaction volume and nested PCR was performed with a second gene-specific 18-mer primer (region 3434-3451 of clone 3) and a $3^{\prime}$ anchor primer (5'-TAGTTCTAGATCGCGAGCGG-3') generated from the Not1 primer adapter. This second PCR was similar to the first except that the annealing temperature was $65^{\circ} \mathrm{C}$ and the number of cycles was 35 . The PCR product, which migrated at $\sim 600 \mathrm{bp}$, was subcloned into the TA cloning vector (Stratagene, La Jolla, CA) and sequenced as above from the $3^{\prime}$ end.

Transient expression in HeLa cells and transport assays. The fulllength clone 3 cDNA, subcloned in pSPORT1 with coding strand downstream of the $\mathrm{T} 7$ promoter, was transfected into cultured mammalian cells as follows. HeLa cells grown on 35-mm dishes were infected for 30 min with recombinant vaccinia vTF7-3 (45), the medium was changed, and the cells were then transfected by adding premixed cDNA $(10 \mu \mathrm{g})$ and Lipofectin $(20 \mu \mathrm{g}$, Gibco-BRL), after which there was an additional medium change at $3 \mathrm{~h}$. The plasmid pBluescript KS was used as a negative control.

After $20 \mathrm{~h}$, cells were washed, ${ }^{3}[\mathrm{H}]-\mathrm{PG}$ was added in Waymouth's solution, and timed uptake at $27^{\circ} \mathrm{C}$ was determined. Uptake was stopped by one cold wash using Waymouth's with 5\% BSA and three cold washes with Waymouth's only. Cells were scraped and counted by liquid scintillation. On Fig. 2, data are the mean \pm SEM of two dishes from each of two separate monolayer transfections.

For determining PG uptakes (see Fig. 2), the following ${ }^{3}[\mathrm{H}]-\mathrm{PGs}$ and final concentrations were used (New England Nuclear, Boston, MA): $P_{G_{2}}: 0.7 \mathrm{nM}(176 \mathrm{cpm} / \mathrm{fmol}) ; \mathrm{PGE}_{1}: 0.6 \mathrm{nM}(62 \mathrm{cpm} / \mathrm{fmol})$; $\mathrm{PGD}_{2}: 0.9 \mathrm{nM}(126 \mathrm{cpm} / \mathrm{fmol}) ; \mathrm{PGF}_{2 \alpha}: 0.6 \mathrm{nM}(185 \mathrm{cpm} / \mathrm{fmol})$; and $\mathrm{TXB}_{2}: 1.0 \mathrm{nM}(114 \mathrm{cpm} / \mathrm{fmol})$. In addition, the $\mathrm{PGI}_{2}$ analog ${ }^{3}[\mathrm{H}]$-iloprost was used (Amersham Corp., Arlington Heights, IL) at $7.9 \mathrm{nM}$ $(14 \mathrm{cpm} / \mathrm{fmol})$.

Inhibition of tracer $P G E_{2}$ uptake. Tracer $\mathrm{PGE}_{2}$ uptakes at 10 $\min \left(0.2 \mathrm{nM}^{3}[\mathrm{H}]-\mathrm{PGE}_{2}\right)$ with or without various concentrations of unlabeled prostanoids (100-500 nM; Cayman Chemical, Ann Arbor, MI) or inhibitors (10-100 $\mu \mathrm{M}$, Sigma Chemical Co., St. Louis, MO) were determined in duplicate on a given transfection for one or two separate transfections. Because the substrate concentration was at least 500 times less than the concentration of the unlabeled prostanoid, we defined an apparent affinity constant, $\mathrm{K}_{1 / 2}$, from the equation:

$K_{1 / 2}=\left[v_{i} /\left(v-v_{i}\right)\right][i]$

where $\mathrm{v}=$ uptake without inhibitor, $\mathrm{v}_{\mathrm{i}}=$ uptake with inhibitor, and [i] = inhibitor concentration (46).

Northern blot hybridization. Based on preliminary data indicating that a rat probe lacking much of the $3^{\prime}$ untranslated region gave lower backgrounds, the rat PGT cDNA was shortened by restriction digesting it with BamH1 and religating the remaining fragment, such that the resulting cDNA terminates at nucleotide 2055. An antisense digoxigenin-labeled RNA probe was generated from this clone using SP6 polymerase (Boehringer Mannheim Biochemicals) after linearizing with Sal1. A human PGT digoxigenin-labeled antisense probe was similarly generated from EcoR1-linearized clone 3 that had been previously shortened and religated at the $3^{\prime}$ end using Acc1. As a housekeeping probe, human $\beta$-actin cDNA (Prime-It II, Stratagene) was labeled by the random primer method with $\left[\alpha{ }^{-32} \mathrm{P}\right] \operatorname{dCTP}(3,000 \mathrm{Ci} /$ mmol; New England Nuclear).

Rat whole kidney total RNA, prepared by the acid guanidinium method (47), and $1 \mu \mathrm{g}$ of human kidney poly-A+ RNA (Clontech, Palo Alto, CA) were separated by glyoxal denaturing agarose electrophoresis (44) and transferred to Hybond-N nylon membranes (Amersham Corp.). Separately, four multiple human tissue Northern blots were purchased from Clontech.

Blots probed with either the rat PGT or the clone $3 \mathrm{hPGT}$ riboprobes were hybridized overnight at $65^{\circ} \mathrm{C}$ in $5 \times \mathrm{SSC}, 50 \%$ formamide, $2 \%$ blocking reagent, $0.1 \% \mathrm{~N}$-laurylsarcosine, $0.02 \% \mathrm{SDS}$, and 0.01 M EDTA (Genius System; Boehringer Mannheim Biochemicals). This was followed by sequential washes at $65^{\circ} \mathrm{C}$ : twice in $1 \times$ SSC, $0.1 \%$ SDS, $0.01 \mathrm{M}$ EDTA; twice in $0.5 \times$ SSC, $0.1 \%$ SDS, $0.01 \mathrm{M}$ EDTA; and twice in $0.1 \times$ SSC, $0.1 \%$ SDS, 0.01 M EDTA. For the $\beta$-actin probe of the same membranes, hybridization was in $5 \times$ SSC, $2 \%$ blocking reagent, $0.1 \% N$-laurylsarcosine, $0.02 \%$ SDS, and $0.01 \mathrm{M}$ EDTA overnight at $65^{\circ} \mathrm{C}$. These blots were washed at $65^{\circ} \mathrm{C}$, twice in $1 \times$ SSC, $0.1 \%$ SDS, $0.01 \mathrm{M}$ EDTA; twice in $0.5 \times$ SSC, $0.1 \%$ SDS, $0.01 \mathrm{M}$ EDTA; and twice in $0.1 \times$ SSC, $0.1 \%$ SDS, $0.01 \mathrm{M}$ EDTA.

Detection was performed using a horseradish peroxidase-coupled antidigoxigenin antibody (Fab fragment) (Boehringer Mannheim Biochemicals). Signals were visualized by chemiluminescence autoradiography (ECL, Amersham Corp.).

\section{Results}

To search for human homologues of rat PGT, we first examined adult human kidney RNA by Northern blotting it with a rat PGT antisense RNA probe. Fig. 1 shows that the rat probe revealed two bands of $\sim 4.0$ and $4.7 \mathrm{~kb}$ in total rat kidney RNA, as previously reported (36). When applied to human adult kidney poly A + RNA at the same high stringency, the rat probe hybridized strongly to bands of 2.3 and $4.2 \mathrm{~kb}$, and weakly to bands of 6.0 and $7.0 \mathrm{~kb}$ (Fig. 1). These results suggested that there was a human PGT homologue, with perhaps several PGT transcripts expressed in human kidney.

To understand the human homologue further, we screened an adult human kidney cDNA library with a ${ }^{32} \mathrm{P}$-labeled rat PGT DNA probe. Seven hybridizing clones were isolated. After preliminary DNA sequencing and restriction mapping, six of the seven clones appeared to be related to each other and to rat PGT, and so were subjected to a more detailed analysis.

The longest clone isolated (No. 3) was $3.5 \mathrm{~kb}$ in length. Preliminary sequencing of this clone at the $5^{\prime}$ end revealed simi- 


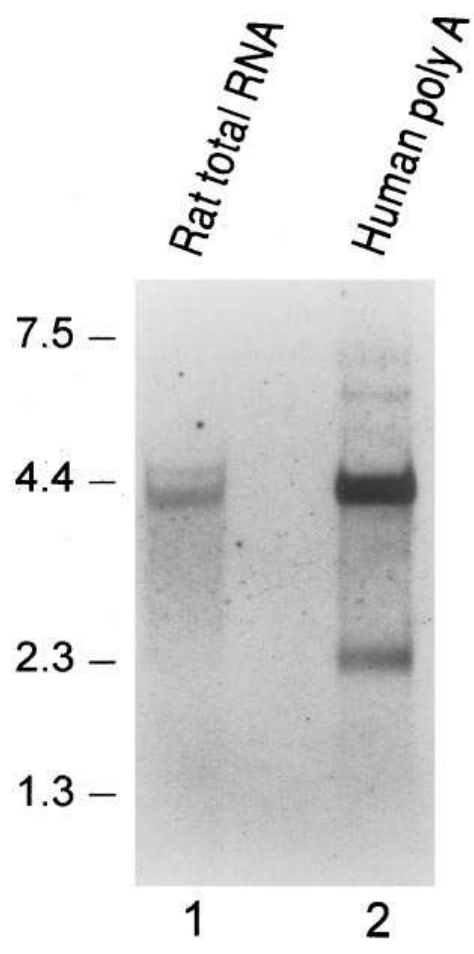

Table I. Inhibition of hPGT-mediated Tracer PGE $E_{2}$ Transport

\begin{tabular}{lcc}
\hline Inhibitor* & $10 \mu \mathrm{M}$ & $100 \mu \mathrm{M}$ \\
\hline Furosemide & $91.5 \pm 3.3$ & $63.3 \pm 1.7$ \\
Probenecid & $104 \pm 5.2$ & $92.8 \pm 2.0$ \\
Indomethacin & $114 \pm 3.8$ & $82.5 \pm 1.0$ \\
Unlabeled Prostanoid & $100 \mathrm{nM}$ & $500 \mathrm{nM}$ \\
\hline $\mathrm{PGE}_{1}$ & $50.8 \pm 3.4$ & - \\
$\mathrm{PGE}_{2}$ & $45.2 \pm 1.4$ & - \\
$\mathrm{PGD}_{2}$ & $47.9 \pm 0.9$ & - \\
$\mathrm{PGF}_{2 \mathrm{a}}$ & $45.0 \pm 1.3$ & - \\
$\mathrm{TXB}_{2}$ & - & $26.7 \pm 0.1$ \\
\end{tabular}

Uptakes were determined \pm various inhibitors or unlabeled prostanoids. Results are shown as the percentage of the control 10-min tracer $\mathrm{PGE}_{2}$ uptake. *Mean \pm SEM from four separate determinations. ${ }^{*}$ Mean \pm SEM from two separate determinations.
Figure 1. Northern blot hybridization of rat kidney total RNA $(35 \mu \mathrm{g})$ and human kidney poly A + RNA $(1 \mu \mathrm{g})$ using a rat PGT antisense RNA probe. Hybridization and washing conditions as per Methods. larity to rat PGT, including an ATG codon in good context for translation initiation (48). Before proceeding with sequencing, we tested the function of clone 3 using the vaccinia-T7 system $(36,45)$, on the assumption that mediation of PG transport would indicate that the clone did not contain splice artifacts causing frame shifts or premature stop codons.

Fig. 2 shows that clone 3 catalyzed the rapid and timedependent uptake of several PGs. The 2-min rank-order of uptakes is $\mathrm{PGE}_{2}>\mathrm{PGE}_{1}>\mathrm{PGF}_{2 \alpha}>\mathrm{PGD}_{2}>\mathrm{TXB}_{2}$. By 10 and $20 \mathrm{~min}$, there is essentially no difference between the transport rates of $\mathrm{PGE}_{2}, \mathrm{PGE}_{1}, \mathrm{PGF}_{2 \alpha}$, or $\mathrm{PGD}_{2}$. In contrast, the prostacyclin analogue iloprost was not transported above baseline (data not shown). With the exception of the information on the transport of $\mathrm{PGD}_{2}$, which is new to the present study, this rank order is very similar to that of rat PGT, as we recently reported (36). Because of the new finding here of $\mathrm{PGD}_{2}$ transport by hPGT, we reexpressed rat PGT in HeLa cells, and found that rat PGT also transports tracer $\mathrm{PGD}_{2}$ at a rate equivalent to that of $\mathrm{PGE}_{2}$ (data not shown). Taken together, the data of Fig. 2 indicate that clone 3 very likely represents a human homologue of rat PGT.

Table I presents results using three known PG transport inhibitors. Although furosemide was a moderately potent inhibitor of hPGT, probenecid and indomethacin were much less effective. Table I also shows the inhibition of tracer $\mathrm{PGE}_{2}$ by an excess of unlabeled prostanoids, assessed using clone 3 . The apparent affinity constants $\left(K_{1 / 2}\right.$, in $\left.\mathrm{nM}\right)$ were: $\mathrm{PGE}_{2}=100$, $\mathrm{PGD}_{2}=83, \mathrm{PGF}_{2 \alpha}=92, \mathrm{PGE}_{1}=82$, and $\mathrm{TXB}_{2}=182$. (It

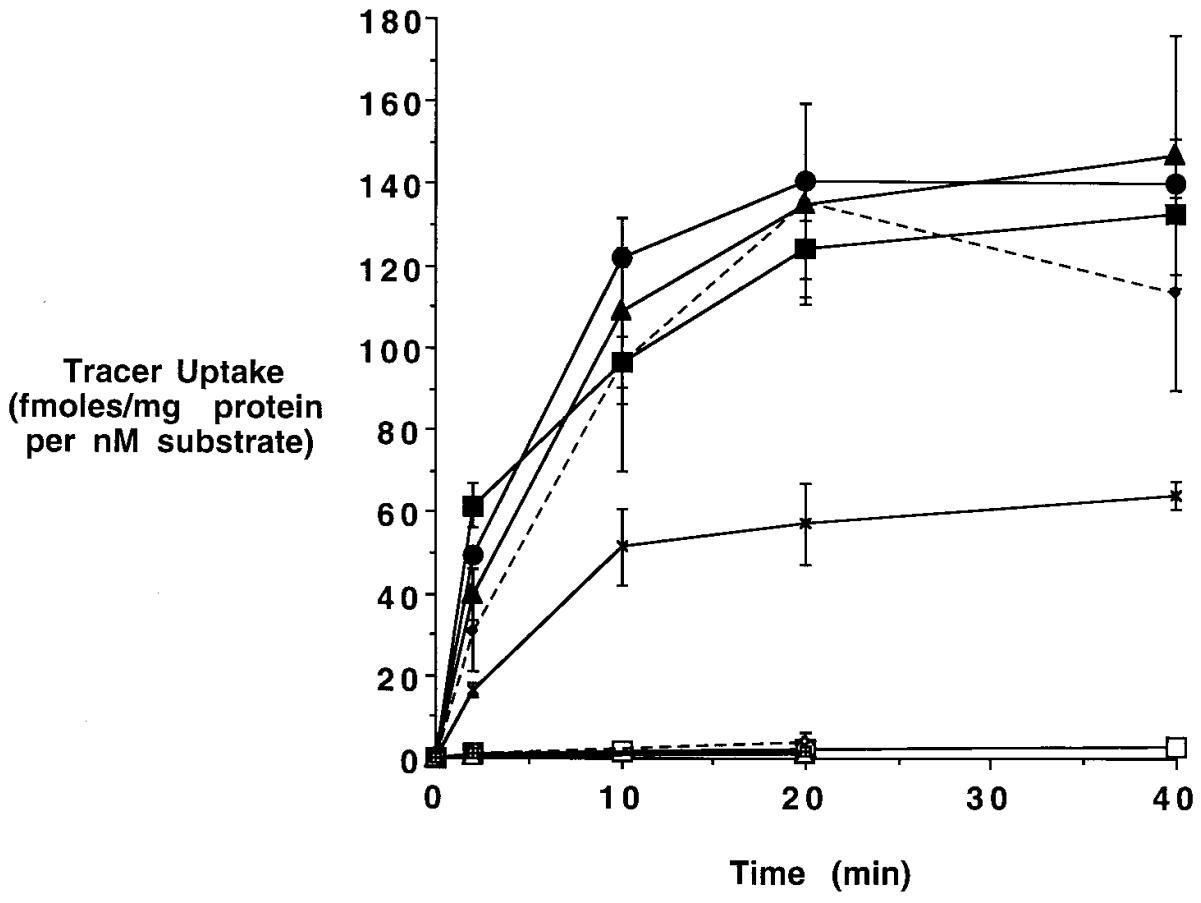

Figure 2. Time-dependent uptake of tracer prostaglandins into HeLa cells expressing clone 3. $P G T$, vector contained clone 3 cDNA; $p B S$, vector was pBluescript control without any PGT sequence. --, PGE2, PGT; $\square-$, PGE2, pBS; - PGE1, PGT; - - -, PGE1, pBS; $\triangle$, PGF $2 \alpha$, PGT; $\triangle$ PGF $2 \alpha, \mathrm{pBS}$ $\checkmark-$, PGD2, PGT; $-\cdots$, PGD2, pBS; $\times$ TxB2, PGT; $\square$, TxB2, pBS. 


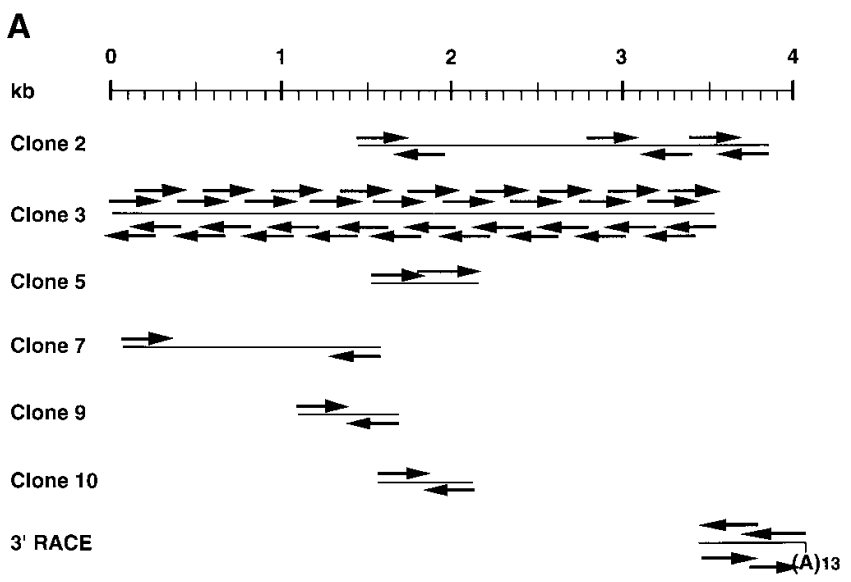

B

hPGT MGLLPKLGVS QGSDTSTSRA GRCARSVFGN IKVFVLCOGL LQLCQLLYSA

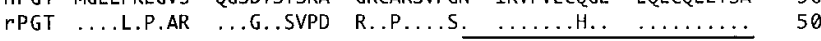
hPGT YFKSSLTTIE KRFGLSSSSS GLISSLNEIS NAILIIFVSY FGSRVHRPRL 100

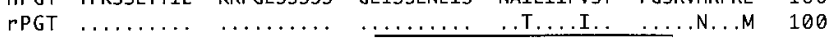
hPGT IGIGGFLAA GAFILTLPHF LSEPYQYTLA STGNNNSRLQA ELCQKHWQDL 150

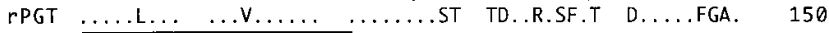

hPGT PPSKCHSTTQ NPQKETSSMW GLMVVAQLLA GIGTVPIQPF GISYVDDFSE 200

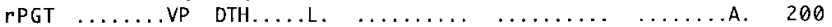

hPGT PSNSPLYISI LFAISVFGPA FGYLLGSIML OIFVDYGRVN TAAVNLVPGD 250

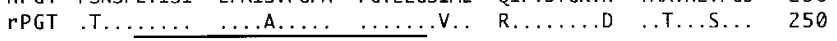

hPGT PRWIGAWWLG LLISSALLVL TSFPFFFFPR AMPIGAKRAP ATADEARKLE 300

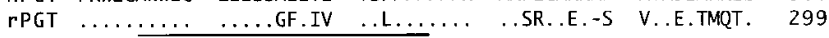

hPGT EAKSRGSLVD FIKRFPCIFL RLLMNSLFVL VVLAQCTFSS VIAGLSTFLN 350

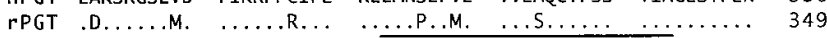

hPGT KFLEKQYGTS AAYANFLIGA VNLPAAALGM LFGGILMKRF VFSLQTIPRI 400

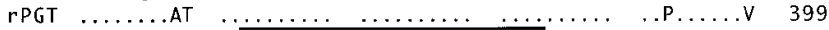

hPGT ATTIITISMI LCVPLFFMG STPTVAEVYP PSTSSSIHPQ SP-ACRRDCS 449

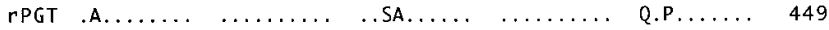

hPGT CPDSIFHPVC GDNGIEYLSP CHAGCSNINM SSATSKQLIY LNCSCVTGGS 499 rPGT ...F.... ...V..V.. .....ST.T ..EA..EP.. ........ 499

hPGT ASAKTGSCPV PCAHFLLPAI FLISFVSLIA CISHNPLYMM VLRVVNQEEK 549 rPGT ..QDRLMPH. LR. - L...S. ....AA... . ............... 548

hPGT SFAIGVQFLL MR̊LLAWLPSP ALYGLTIDHS CIRWNSLCLG RRGACAYYDN 599

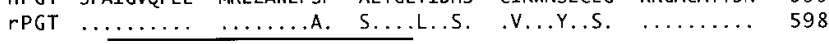

hPGT DALRDRYLGL QMGYKALGML LLCFISWRVK KNKEYNVQ-K AAGLI 643

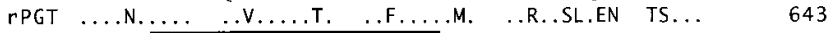

Figure 3. (A) Sequencing map of hPGT clones. Arrows indicate direction and length of dideoxy DNA sequencing runs. $(B)$ Deduced amino acid sequence of hPGT compared to that of rat PGT. Dots in the hPGT sequence represent identity to rat PGT. (Underlines) putative membrane-spanning domains. (Black circles) charged residues within putative membrane spans that are conserved between hPGT, rat PGT, and the related transporter oatp (50). *Potential glycosylation sites.

should be noted that, because tracer uptake in the presence of unlabeled PGs was determined at $10 \mathrm{~min}$ and does not represent an initial value, $K_{1 / 2}$ approximates, but does not equal, the Michaelis-Menten constant $K_{\mathrm{m}}$ ).

Fig. $3 A$ shows the sequencing strategy and alignments of the six cDNA clones examined from the human kidney cDNA library. Clones No. 2 and 3 overlap and cover a total distance of $3.8 \mathrm{~kb}$ (Fig. $3 A$ ). The $3^{\prime}$ end of clone 3 was used to generate two gene-specific primers for a $3^{\prime}$ RACE strategy to clone the remaining $3^{\prime}$ untranslated region. As described in Methods, and as illustrated in Fig. $3 \mathrm{~A}$, a PCR product of $612 \mathrm{bp}$ was amplified, cloned, and sequenced. This yielded $400 \mathrm{bp}$ that overlap with the $3^{\prime}$ end of clone 2 , as well as 212 new nucleotides that terminate in a poly-A tail. The total length of the cDNA sequence assembled from clone 2 , clone 3 , and the 3 ' RACE sequence comprised 4,046 bp, which is in reasonable agreement with the size of the major transcript in most tissues $(\sim 4.2$ kb, Figs. 4-6 below).

The consensus hPGT cDNA sequence, derived from all five clones, was $74 \%$ identical to that of the available comparable rat PGT cDNA sequence. There was also strong homology to several expressed sequence tags in the human database (Genbank accession numbers H63820, H63772, T85296, R25350, T85507, and R26541).

Fig. $3 B$ compares the deduced amino acid sequences of hPGT and rat PGT starting at comparable ATG translation initiation codons (position 88 in the rat and 92 in the human). The predicted rat and human proteins are highly similar $(82 \%$ identity). hPGT is predicted to have 12 membrane-spanning domains based on the Kyte-Doolittle hydropathy algorithm using a window of 13 residues (49). Glycosylation of hPGT could occur at any or all of three extracytoplasmic asparagine consensus sites (Fig. 3 B).

In addition to its similarity to rat PGT, the hPGT deduced protein sequence is $32 \%$ identical to human organic anion transporting polypeptide (oatp). Like PGT, oatp has been shown to be an organic anion transporter, primarily of bile salts and conjugated steroids $(50,51)$. It is therefore of interest that three charged residues in hPGT (E77, R561, and K614, see Fig. 3 B), which lie within putative membrane spans, are highly conserved between hPGT, rat PGT, and oatp (50), suggesting that these amino acids may play an important role in anion transport.

We examined the tissue distribution of hPGT expression in adult human tissues by Northern blot analysis of poly $\mathrm{A}+$ RNA (Fig. 4, $A$ and $B$ ). A diversity of hybridizing transcripts was observed. The most strongly hybridizing RNA bands were $1.8-2.0 \mathrm{~kb}$ in skeletal muscle, prostate, testis, ovary, small intestine, and colon; $2.5-2.9 \mathrm{~kb}$ in heart and skeletal muscle; 4.0 $\mathrm{kb}$ in ovary; 4.4-5.1 kb (often a doublet) in heart, whole brain, placenta, lung, liver, skeletal muscle, kidney, spleen, thymus, prostate, testis, ovary, small intestine, colon, and peripheral blood leukocytes; $8.8 \mathrm{~kb}$ in testis and colon; and $10.1 \mathrm{~kb}$ in testis. (The RNA derived from pancreas appeared to undergo some degradation, so statements about the exact PGT message in that organ remain limited).

Further examination of specific regions of the human brain by Northern blotting revealed major transcripts of 2.1, 3.5, 4.8, and $7.5 \mathrm{~kb}$ in most regions, with an additional $10-\mathrm{kb}$ band seen in the caudate nucleus (Fig. 5). Although it is possible that the $2.1-\mathrm{kb}$ bands represents the riboprobe probe binding to $18 \mathrm{~S}$ RNA, this seems unlikely because this blot utilized poly-A+ RNA, not total RNA, and because we do not see carry-over of ribosomal RNA in the other blots. Moreover, the presence of strong bands of similar size in fetal lung, and in adult prostate, testis, ovary, small intestine, colon, and skeletal muscle argue that the 2.1-kb bands in brain derive from mRNA. 
A
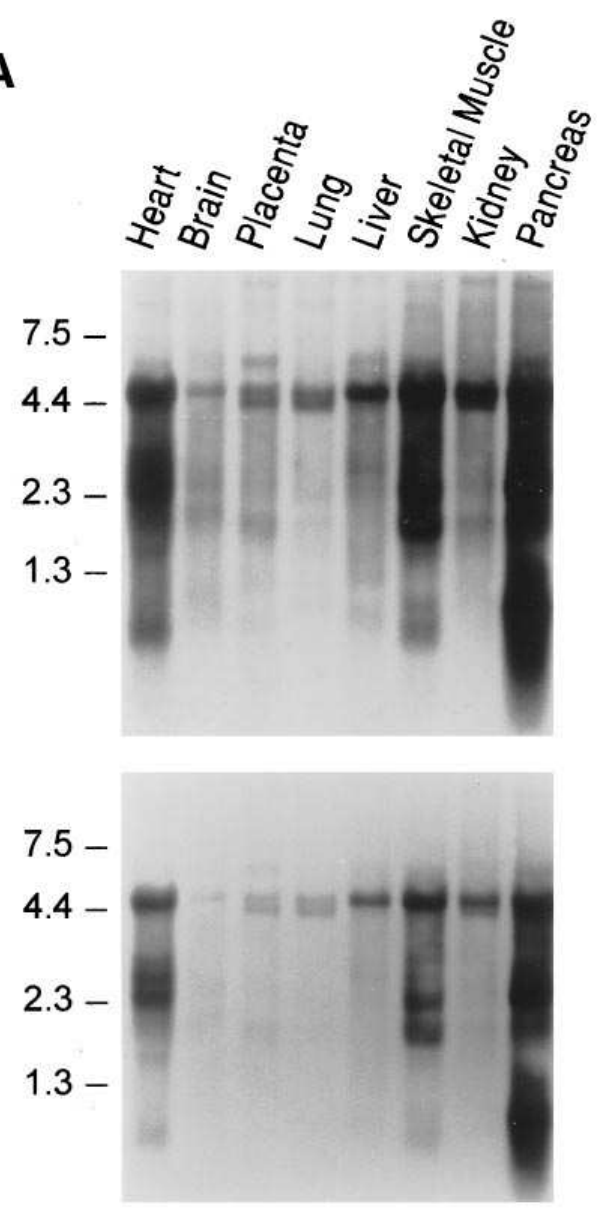

$\beta$ Actin $>$
B
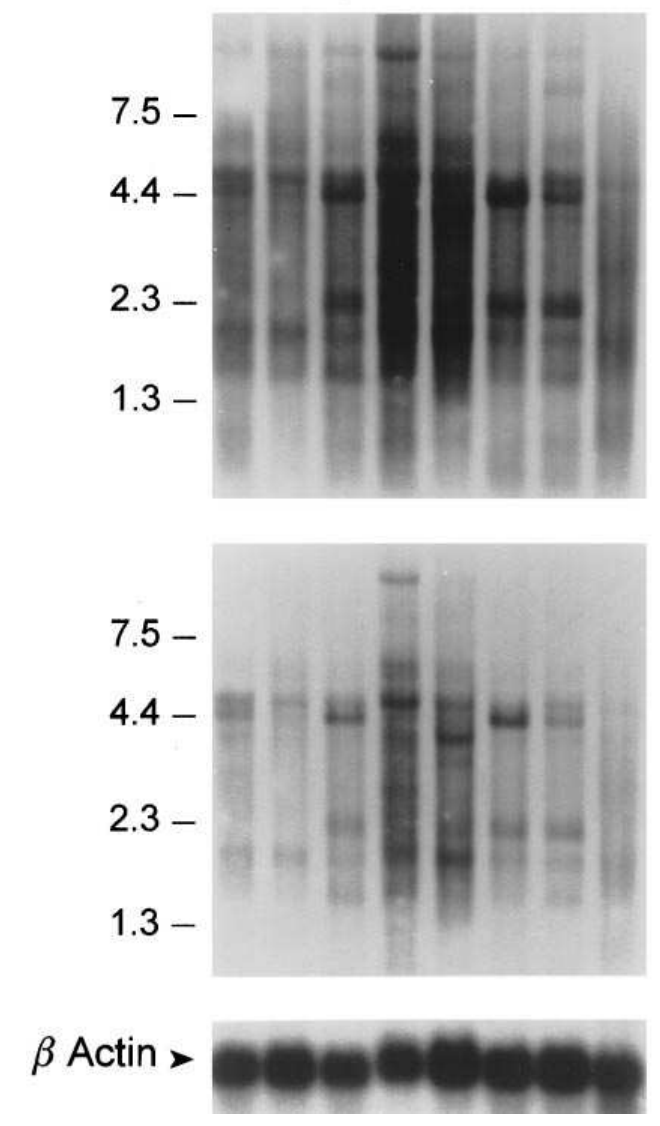

$\beta$ Actin

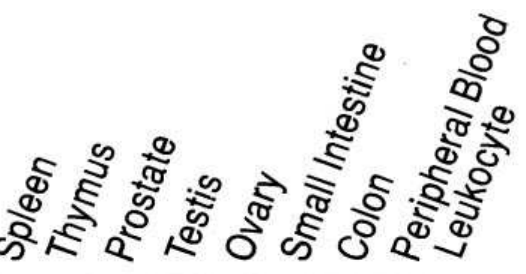

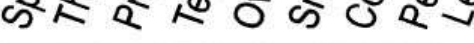

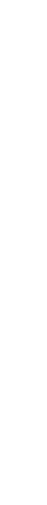

Figure 4. $(A$ and $B)$ Northern blot hybridization of human poly A+ RNA using a human PGT clone 3 antisense RNA probe. Hybridization and washing conditions as per Methods. Top panels represent exposure overnight, middle panels represent exposure for 15 min.

In human fetal tissues (Fig. 6), the RNA transcripts seen by Northern blot hybridization were $2.1 \mathrm{~kb}$ in brain, lung, liver, and kidney; $2.5 \mathrm{~kb}$ in lung; 4.8-5.1 kb in brain, lung, liver, and kidney; $6.1 \mathrm{~kb}$ in liver; and $10 \mathrm{~kb}$ in lung and liver.

\section{Discussion}

We have cloned, sequenced, and heterologously-expressed a human homologue (hPGT) of PGT, a newly-recognized prostaglandin transporter that we previously identified in the rat (36). The hPGT nucleic acid and deduced amino acid sequences are similar to that of the rat transporter. In vitro expression of a full-length hPGT cDNA causes the transport of $\mathrm{PGE}_{1}, \mathrm{PGE}_{2}, \mathrm{PGD}_{2}, \mathrm{PGF}_{2 \alpha}$, and to a lesser extent $\mathrm{TXB}_{2}$. The mRNA expression for hPGT in native human tissues is very broad. Indeed, hPGT mRNA was seen in essentially every tissue or cell type examined, and there is a rich diversity of mRNA transcripts ranging from 1.8 to over $10 \mathrm{~kb}$ in length.

Although there is a substantial literature on carrier-mediated PG transport in other species (19-36), there is surprisingly little information about this phenomenon in humans, perhaps because of difficulty in obtaining tissue for such studies. $\mathrm{PGE}_{2}$ has been shown to be transported by the isolated perfused human placental cotyledon (52) and by the isolated human amnion (35). Despite this paucity of direct information, the literature in animals, taken with the present functional profile and broad tissue expression pattern of hPGT, make it very likely that extensive carrier-mediated PG transport occurs in diverse human tissues.

As discussed in the Introduction, it appears that PGT most likely plays a role in the uptake of newly released PGs before intracellular oxidation. In this regard, the affinities of hPGT for its substrates are of interest. Despite the observation that hPGT and rat PGT both transport $\mathrm{TXB}_{2}$ at a rate about half that of $\mathrm{PGE}_{2}$ or $\mathrm{PGF}_{2 \alpha}$ (36) (Fig. 2), the $K_{1 / 2}$ of hPGT for this substrate is half that of the rat affinity constant (182 vs $423 \mathrm{nM}$, respectively, Table I and [36]), suggesting that PGT may play a more prominent role in thromboxane transport in the human than in the rat. Further studies will be required to address this possibility directly.

The apparent affinities $\left(K_{1 / 2}\right)$ of hPGT for $\mathrm{PGE}_{2}$ and $\mathrm{PGF}_{2 \alpha}$ are in the range of $80-100 \mathrm{nM}$. PG concentrations as presented 

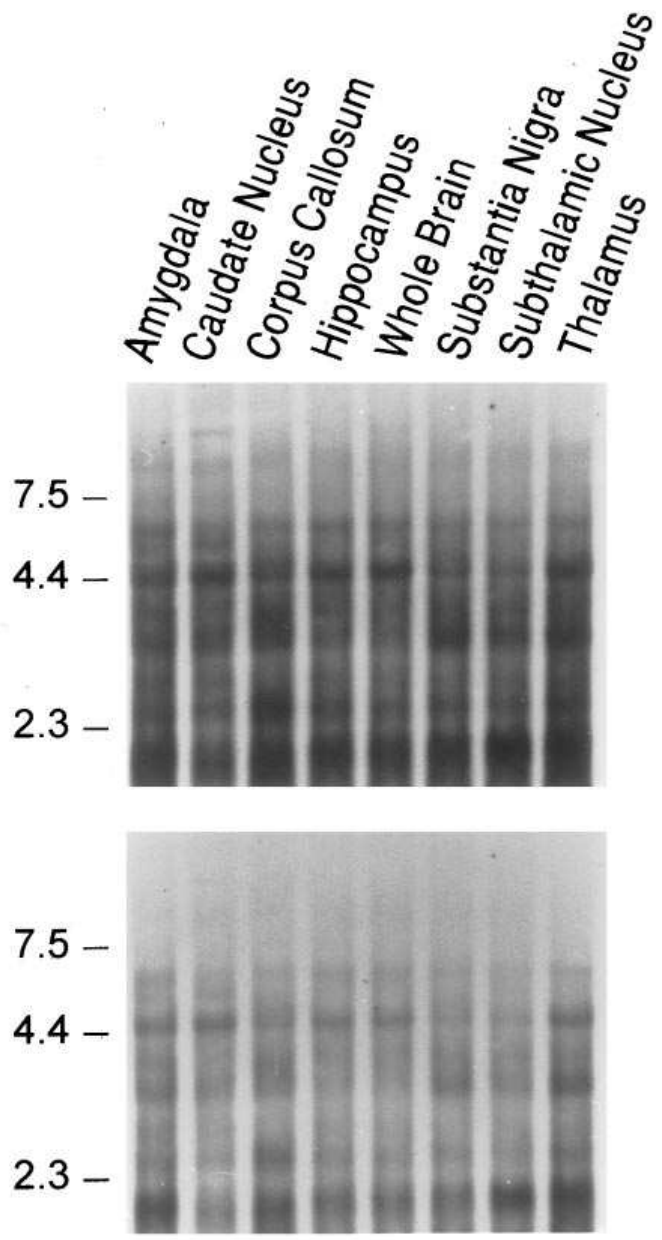

$\beta$ Actin

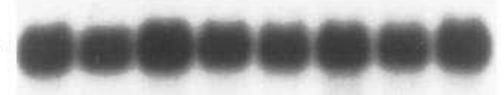

Figure 5. Northern blot hybridization of human brain poly A+ RNA using a human PGT clone 3 antisense RNA probe. Hybridization and washing conditions are as per Fig. 4. Top panels represent exposure for $1 \mathrm{~h}$, middle panels represent exposure for $5 \mathrm{~min}$.

to the transporter in tissues are probably at least this high. In human lung, for example, the $\mathrm{PGE}_{2}$ concentration is about 25 $\mathrm{ng}$ /gram tissue, or $\sim 70 \mathrm{nM}$; in human semen this value is $\sim 25$ $\mu \mathrm{g} / \mathrm{ml}$, or $\sim 70 \mu \mathrm{M}$ (53). On the other hand, plasma PGE and PGF concentrations in humans are $\sim 0.25 \mathrm{ng} / \mathrm{ml}$, or $0.7 \mathrm{nM}$ (54). Assuming that hPGT is the mechanism for reuptake of PGs after their release, this plasma concentration would represent the residual from such a process.

Many transporters exist in families whose individual members recognize structurally related, but distinct, substrates. It is therefore possible that transporters for other prostanoids exist. Indeed, PGT appears to be part of a gene family, the other currently recognized member of which is oatp (36). Work is currently underway to identify and characterize such PGT-related cDNAs.

The presence of many different mRNA transcripts on high stringency Northern blots suggests that several functionally distinct mRNAs may arise from a single hPGT gene. Such diverse hPGT transcripts could arise by alternative splicing and/ or alternative promoters. At present, we have no definitive in- formation with which to distinguish between these possibilities. However, we have recently isolated human genomic PGT clones (Lu, R., and V.L. Schuster, unpublished observations), a step that should aid in addressing the origin of the diverse transcripts.

We also have no information at present as to whether transcripts that are either substantially larger or smaller than the $\sim 4.0 \mathrm{~kb}$ cDNA encode functional transporters. It is of interest, however, that in neither the rat nor the human cDNA is the first methionine codon preceded by a stop codon (36). This raises the interesting possibility that the larger mRNA transcripts (e.g., the strong $\sim 10$-kb band in testis) might encode proteins that are extended at the amino-terminus relative to the present hPGT consensus cDNA. Confirmation of this hypothesis, as well as functional evaluation of any additional encoded proteins, must await isolation and characterization of additional cDNAs.

The presence of strongly hybridizing hPGT mRNA transcripts in human heart and skeletal muscle stands in contrast to our findings in the rat, where there was no detectable expression, at least by Northern blot analysis, in these two tissues (36). At present, we have no clear explanation for this difference other than species. The unequivocal expression of PGT mRNA in human heart and skeletal muscle argues against our
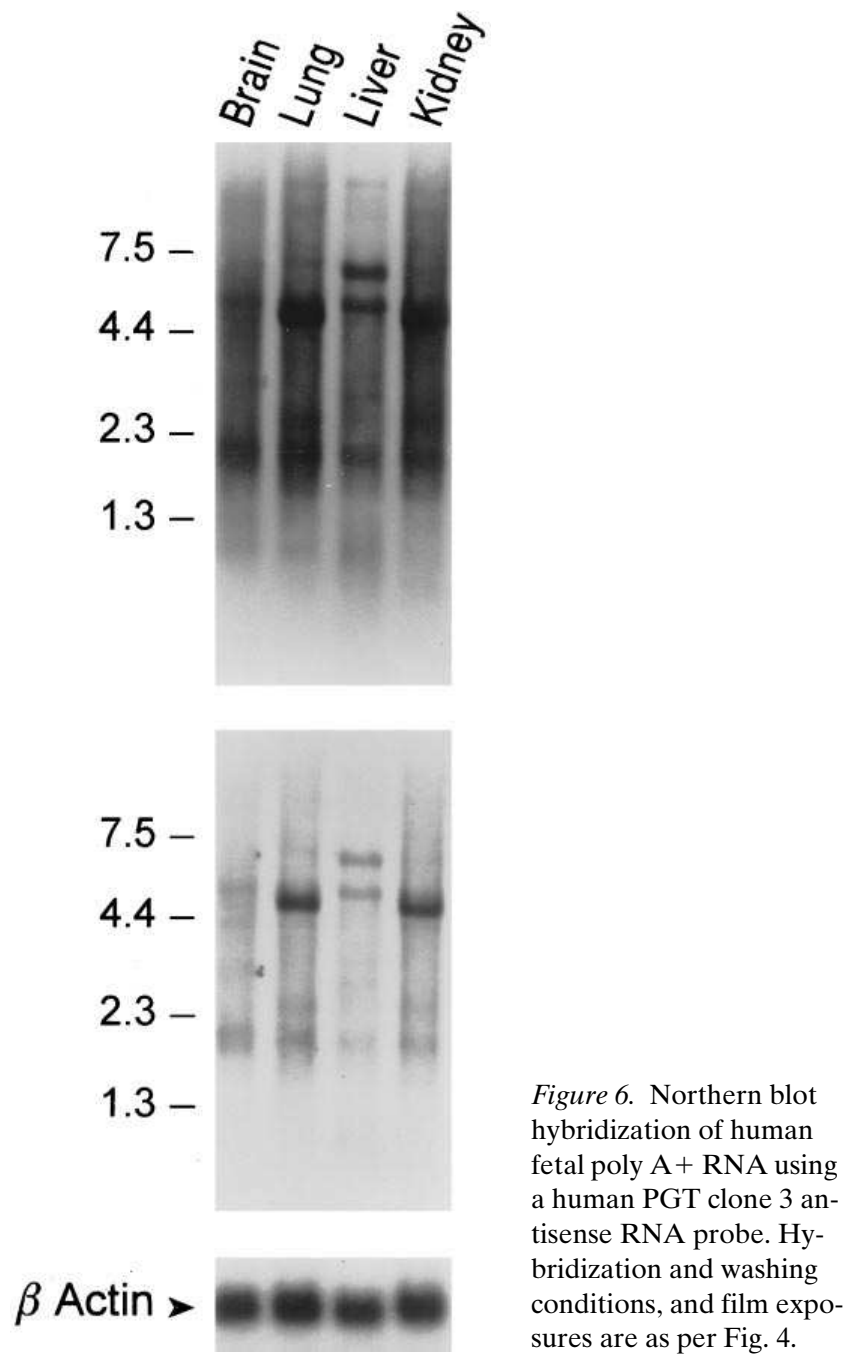
previous conclusion that PGT is restricted to tissues containing epithelia (36). Because human hearts synthesize $\mathrm{PGE}_{2}, \mathrm{PGF}_{2 \alpha}$, and 6-keto-PGF ${ }_{1 \alpha}$, especially in response to cold pressor testing (55-58), it is possible that PGT plays an as yet unidentified role in cardiac prostanoid metabolism.

The novel observation in the present paper of $\mathrm{PGD}_{2}$ transport by both rat and human PGT is of considerable physiological interest. $\mathrm{PGD}_{2}$ has been implicated in several processes in the central nervous system (CNS), including the control of body temperature (59) and of olfactory function, hormone release, and pain perception (60). In addition, both $\mathrm{PGE}_{2}$ and $\mathrm{PGD}_{2}$ have been postulated to mediate central sleep-wake cycles $(59,61,62)$. $\mathrm{PGE}_{2}$ receptors are very widely expressed in diverse structures of the rat brain (63). The equally broad expression of hPGT mRNA in the human brain (Fig. 6), and the ability of cloned hPGT to transport $\mathrm{PGE}_{2}$ and $\mathrm{PGD}_{2}$ approximately equally well (Fig. 2), suggest that the transporter may play a role in the release, epithelial transport, and/or degradation of these prostanoids in the CNS. The present findings provide probes that should be useful in further studies on the CNS function of these eicosanoids.

There are other possible clinical implications of the present work. First, circulating PG levels are elevated in several clinical circumstances, including bone marrow transplantation (64) and the hyperprostaglandin syndrome. The latter is a Bartter syndrome-like complex tubular disorder found in premature infants, characterized by increased systemic $\mathrm{PGE}_{2}$ activity, fever, diarrhea, and osteopenia with hypercalciuria $(65,66)$. One hypothesis to explain these conditions would be a failure to clear circulating $\mathrm{PGE}_{2}$ secondary to abnormal regulation or functional impairment of hPGT.

Second, various synthetic $\mathrm{PGE}_{1}$ or $\mathrm{PGE}_{2}$ analogs have been used to treat glaucoma $(10,11,67)$ and impotence $(68)$, to terminate pregnancy (12), and to provide gastric protection (13-15). The clinical use of these agents is predicated on certain assumptions about their pharmacokinetics, yet with few exceptions (69) detailed information about the clearance and metabolism of these agents in humans is lacking. Only recently, for example, was exogenous $\mathrm{PGE}_{1}$ shown to be rapidly converted to circulating 13,14 -dihydro- $\mathrm{PGE}_{1}$ and 15 -keto-PGE $\mathrm{PG}_{1}$ in humans $(70,71)$. The role of hPGT, if any, in the clearance from the circulation of medicinal PGs can now be approached experimentally by expressing the transporter in vitro and evaluating its interactions with these agents. Moreover, in theory, at least, it should be possible to use the cDNA to design synthetic PGs that are not transported by hPGT, and thus might be cleared more slowly than those that are transported.

In summary, we have cloned, sequenced and heterologously expressed a novel human PG transporter cDNA (hPGT), and have characterized the expression of hPGT mRNA in a large number of human tissues. The substrate specificity and broad tissue distribution suggest a role in the clearance and metabolism of several important endogenous prostanoids.

\section{Acknowledgments}

This work was supported by National Institute of Health grant R01DK-49688; American Heart Association and New York Heart Association Grants-in-Aid; Irma T. Hirschl-Monique Weill-Caulier Career Scientist Award; and fellowships from the Japanese Education Ministry and the National Kidney Foundation of New York/New Jersey.

\section{References}

1. Samuelsson, B. 1990. Prostaglandins and related compounds: Seventh International Conference, Florence, Italy. Adv. Prostaglandin Thromboxane Leukotriene Res. 21A-B. 1012 pp.

2. Murphy, R.C., and F.A. Fitzpatrick. 1990. Arachidonate related lipid mediators. Methods Enzymol. 187:1-683.

3. Bito, L.Z., and J. Stjernschantz. 1989. The Ocular Effects of Prostaglandins and Other Eicosanoids. Prog. Clin. Biol. Res. 312:1-514.

4. Segal, M.B. 1992. Barriers and Fluids of the Eye and Brain. CRC Press, Boca Raton, FL. 219 pp.

5. Levine, L. 1988. Arachidonate Metabolism in Immunologic Systems. Karger, New York. 214 pp.

6. Epstein, M. 1986. Prostaglandins and the kidney. Am. J. Med. 80:1-84.

7. Gugler, R., J.E. McGuigan, and K. Soderquist. 1986. Prostaglandins in the upper gastrointestinal tract: focus on misoprostol: proceedings of the second international symposium. Dig. Dis. Sci. 31(Suppl.):1-150.

8. Neri Serneri, G.G., J.C. McGiff, R. Paoletti, and G.V.R. Born. 1985 Platelets, prostaglandins, and the cardiovascular system. Adv. Prostaglandin Thromboxane Leukotriene Res. 13:1-393.

9. Quiroga, J., and J. Prieto. 1993. Liver cytoprotection by prostaglandins. Pharmacol. Therap. 58:67-91.

10. Ziai, N., J.W. Dolan, R.D. Kacere, and R.F. Brubaker. 1993. The effects on aqueous dynamics of PhXA41, a new prostaglandin F2 alpha analogue, after topical application in normal and ocular hypertensive human eyes. Arch. Ophthalmol. 111:1351-1358.

11. Alm, A., J. Villumsen, P. Tornquist, A. Mandahl, J. Airaksinen, A. Tuulonen, B. Resul, and J. Stjernschantz. 1993. Intraocular pressure-reducing effect of PhXA41 in patients with increased eye pressure. A one-month study. Ophthalmology. 100:1312-1316.

12. Ulmann, A., L. Silvestre, L. Chemama, Y. Rezvani, M. Renault, C.J. Aguillaume, and E.E. Baulieu. 1992. Medical termination of early pregnancy with mifepristone (RU 486) followed by a prostaglandin analogue. Study in 16,369 women. Acta Obstet. Gynecol. Scand. 71:278-283.

13. Konturek, S.J., N. Kwiecien, W. Obtulowicz, J. Maczka, Z. Hebzda, and J. Oleksy. 1991. Effects of nocloprost on gastric functions in man. Scand. J. Gastroenterol. 26:1145-1151.

14. Kobayashi, K., T. Arakawa, K. Higuchi, and H. Nakamura. 1991. Gastric cytoprotection by ornoprostil, a PGE1 analogue, in human subjects. J. Clin. Gastroenterol. 13 (Suppl. 1):S32-S36.

15. Bardhan, K.D., R. Walker, R.F. Hinchliffe, K. Bose, P. Morris, M. Thompson, E. Toivanen, R.P. Thompson, P. Patrier et al. 1991. Gastric ulcer healing: a comparison of enprostil versus ranitidine. J. Clin. Gastroenterol. 13: $157-162$.

16. Roseman, T.J., and S.H. Yalkowsky. 1973. Physicochemical properties of prostaglandin F2 alpha (tromethamine salt): solubility behavior, surface properties, and ionization constants. J. Pharm. Sci. 62:1680-1685.

17. Uekama, K., F. Hirayama, H. Tanaka, and K. Takematsu. 1978. Partition behavior and ion pair formation of some prostaglandins. Chem. \& Pharm. Bull. (Tokyo). 26:F58.

18. Bito, L.Z., and R.A. Baroody. 1975. Impermeability of rabbit erythrocytes to prostaglandins. Am. J. Physiol. 229:1580-1584.

19. Eling, T.E., and M.W. Anderson. 1976. Studies on the biosynthesis, metabolism and transport of prostaglandins by the lung. Agents Actions. 6:543546.

20. Anderson, M.W., and T.E. Eling. 1976. Prostaglandin removal and metabolism by isolated perfused rat lung. Prostaglandins. 11:645-677.

21. Hawkins, H.J., A.G. Wilson, M.W. Anderson, and T.E. Eling. 1977. Uptake and metabolism of prostaglandins by isolated perfused lung: species comparisons and the role of plasma protein binding. Prostaglandins. 14:251-259.

22. Eling, T.E., H.J. Hawkins, and M.W. Anderson. 1977. Structural requirements for, and the effects of chemicals on, the rat pulmonary inactivation of prostaglandins. Prostaglandins. 14:51-60.

23. Bito, L.Z., and E.V. Salvador. 1976. Effects of anti-inflammatory agents and some other drugs on prostaglandin biotransport. J. Pharmacol. Exp. Ther. 198:481-488.

24. Bito, L.Z., H. Davson, and E.V. Salvador. 1976. Inhibition of in vitro concentrative prostaglandin accumulation by prostaglandins, prostaglandin analogues and by some inhibitors of organic anion transport. J. Physiol. (Lond). 256:257-271.

25. Bito, L.Z., and M.C. Wallenstein. 1977. Transport of prostaglandins across the blood-brain and blood-aqueous barriers and the physiological significance of these absorptive transport processes. Exp. Eye. Res. 25 (Suppl):229-243.

26. Hagen, A.A., J.N. Gerber, C.C. Sweeley, R.P. White, and J.T. Robertson. 1977. Levels and disappearance of prostaglandin F2alpha in cerebral spinal fluid: a clinical and experimental study. Stroke. 8:672-675.

27. DiBenedetto, F.E., and L.Z. Bito. 1986. Transport of prostaglandins and other eicosanoids by the choroid plexus: its characterization and physiological significance. J. Neurochem. 46:1725-1731.

28. Suzuki, F., H. Hayashi, and O. Hayaishi. 1986. Transport of prostaglandin D2 into brain. Brain Res. 385:321-328. 
29. Bikhazi, A.B., G.M. Baasiri, N.Z. Boulos, and R.N. Khuri. 1983. Transport of prostaglandins through normal and diabetic rat hepatocytes. J. Pharm. Sci. 72:296-299.

30. Bito, L.Z. 1973. Absorptive transport of prostaglandins from intraocular fluids to blood: a review of recent findings. Exp. Eye Res. 16:299-306.

31. Bito, L.Z. 1975. Saturable, energy-dependent, transmembrane transport of prostaglandins against concentration gradients. Nature (Lond.). 256:134-136.

32. Jones, M.A., and M.J. Harper. 1983. Prostaglandin accumulation by isolated uterine endometrical epithelial cells from six-day pregnant rabbits. Biol. Reprod. 29:1201-1209.

33. Cao, Z.D., M.A. Jones, and M.J. Harper. 1984. Prostaglandin translocation from the lumen of the rabbit uterus in vitro in relation to day of pregnancy or pseudopregnancy. Biol. Reprod. 31:505-519.

34. Walenga, R.W., D.C. Kuhn, and M.J. Stuart. 1989. Trans-placental transport and metabolism of carbacyclin by perfused human placental in vitro. Prostaglandins. 37:121-134.

35. McCoshen, J.A., D.R. Hoffman, J.V. Kredentser, C. Araneda, and J.M. Johnston. 1990. The role of fetal membranes in regulating production, transport, and metabolism of prostaglandin E2 during labor. Am. J. Obstet. Gynecol. 163:1632-1640.

36. Kanai, N., R. Lu, J. Satriano, Y. Bao, A.W. Wolkoff, and V.L. Schuster. 1995. Identification and characterization of a prostaglandin transporter. Science (Wash. DC). 268:866-869.

37. Morita, I., W.L. Smith, D.L. DeWitt, and M. Schindler. 1995. Expression-activity profiles of cells transfected with prostaglandin endoperoxide $\mathrm{H}$ synthase measured by quantitative fluorescence microscopy. Biochemistry. 34: 7194-7199.

38. Ferreira, S.H., and J.R. Vane. 1967. Prostaglandins: their disappearance from and release into the circulation. Nature (Lond.). 216:868-873.

39. Irish, J.M. 1979. Secretion of prostaglandin E2 by rabbit proximal tubules. Am. J. Physiol. 237:F268-F273.

40. McGiff, J.C., N.A. Terragno, J.C. Strand, J.B. Lee, A.J. Lonigro, and K.K. Ng. 1969. Selective passage of prostaglandins across the lung. Nature (Lond.). 223:742-745.

41. Piper, P.J., J.R. Vane, and J.H. Wyllie. 1970. Inactivation of prostaglandins by the lungs. Nature (Lond.). 225:600-604.

42. Moncada, S., R. Korbut, S. Bunting, and J.R. Vane. 1978. Prostacyclin is a circulating hormone. Nature (Lond.). 273:767-768.

43. Dusting, G.J., S. Moncada, and J.R. Vane. 1978. Recirculation of prostacyclin (PGI2) in the dog. Br. J. Pharmacol. 64:315-320.

44. Sambrook, J., E.F. Fritsch, and T. Maniatis. 1989. Molecular Cloning. A Laboratory Manual. Cold Spring Harbor Laboratory Press, Cold Spring Harbor, NY. 10.13-10.17.

45. Fuerst, T.R., E.G. Niles, F.W. Studier, and B. Moss. 1986. Eukaryotic transient expression system based on recombinant vaccinia virus that synthesizes bacteriophage T7 RNA polymerase. Proc. Natl. Acad. Sci. USA. 83:81228126.

46. Neame, K.D., and T.G. Richards. 1972. Elementary Kinetics of Membrane Carrier Transport. John Wiley \& Sons, New York. 120 pp.

47. Chomczynski, P., and N. Sacchi. 1987. Single-step method of RNA isolation by acid guanidinium thiocyanate-phenol-chloroform extraction. Anal. Biochem. 162:156-159.

48. Kozak, M. 1991. An analysis of vertebrate mRNA sequences: intimations of translational control. J. Cell Biol. 115:887-903.

49. Kyte, J., and R.F. Doolittle. 1982. A simple method for displaying the hydropathic character of a protein. J. Mol. Biol. 157:105-132.

50. Jacquemin, E., B. Hagenbuch, B. Stieger, A.W. Wolkoff, and P.J. Meier. 1994. Expression cloning of a rat liver $\mathrm{Na}^{+}$-independent organic anion transporter. Proc. Natl. Acad. Sci. USA. 91:133-137.

51. Kanai, N., R. Lu, Y. Bao, A.W. Wolkoff, M. Vore, and V.L. Schuster. 1996. Estradiol 17- $\beta$ D-glucuronide is a high-affinity substrate for the organic anion transporter "oatp." Am. J. Physiol. (Renal Fluid Electrolyte Physiol) 270: F326-F331.
52. Glance, D.G., M.G. Elder, and L. Myatt. 1986. Uptake, transfer and metabolism of prostaglandin E2 in the isolated perfused human placental cotyledon. Prostaglandins Leuko. Med. 21:1-14.

53. von Euler, U.S., and R. Eliasson. 1967. Prostaglandins. Academic Press, New York. 164 pp.

54. Zusman, R.M., D. Spector, B.V. Caldwell, L. Speroff, G. Schneider, and P.J. Mulbow. 1973. The effect of chronic sodium loading and sodium restriction on plasma prostaglandin $\mathrm{A}, \mathrm{E}$, and $\mathrm{F}$ concentrations in normal humans. J. Clin. Invest. 52:1093-1098.

55. Neri Serneri, G.G., G.F. Gensini, R. Abbate, D. Prisco, P.G. Rogasi, G.C. Casolo, M. Matucci, F. Fantini, M. Di Donato, and F.P. Dabizzi. 1985 Spontaneous and cold pressor test-induced prostaglandin biosynthesis by human heart. Am. Heart J. 110:50-55.

56. Neri Serneri, G.G., G.F. Gensini, R. Abbate, D. Prisco, P.G. Rogasi, G.C. Casolo, A. Fazi, F. Fantini, M. Di Donato et al. 1986. Impaired cardiac PGI2 and PGE2 biosynthesis in patients with angina pectoris. Am. Heart J. 112: 472-478.

57. Nowak, J., L. Kaijser, and A. Wennmalm. 1980. Cardiac prostaglandin formation in man. Adv. Myocardiology. 1:323-328.

58. Hirsh, P.D., L.D. Hillis, W.B. Campbell, B.G. Firth, and J.T. Willerson. 1981. Release of prostaglandins and thromboxane into the coronary circulation in patients with ischemic heart disease. N. Engl. J. Med. 304:685-691.

59. Sri Kantha, S., H. Matsumura, E. Kubo, K. Kawase, R. Takahata, and C.N. Serhan. 1994. Effects of prostaglandin D2, lipoxins and leukotrienes on sleep and brain temperature of rats. Prostaglandins Leukot. Essent. Fatty Acids. 51:87-93.

60. Ito, S., S. Narumiya, and O. Hayaishi. 1989. Prostaglandin D2: a biochemical perspective. Prostaglandins Leukot. Essent. Fatty Acids. 37:219-234.

61. Matsumura, H., T. Nakajima, T. Osaka, S. Satoh, K. Kawase, E. Kubo, S.S. Kantha, K. Kasahara, and O. Hayaishi. 1994. Prostaglandin D2-sensitive, sleep-promoting zone defined in the ventral surface of the rostral basal forebrain. Proc. Natl. Acad. Sci. USA. 91:11998-12002.

62. Hayaishi, O. 1991. Molecular mechanisms of sleep-wake regulation roles of prostaglandins D2 and E2. FASEB. J. 5:2575-2581.

63. Matsumura, K., Y. Watanabe, K. Imai-Matsumura, M. Connolly, Y. Koyama, and H. Onoe. 1992. Mapping of prostaglandin E2 binding sites in rat brain using quantitative autoradiography. Brain Res. 581:292-298.

64. Cayeux, S.J., P.C. Beverley, R. Schulz, and B. Dorken. 1993. Elevated plasma prostaglandin E2 levels found in 14 patients undergoing autologous bone marrow or stem cell transplantation. Bone Marrow Transplant. 12:603-608.

65. Seyberth, H.W., W. Rascher, H. Schweer, P.G. Kuhl, O. Mehls, and K Scharer. 1985. Congenital hypokalemia with hypercalciuria in preterm infants: a hyperprostaglandinuric tubular syndrome different from Bartter syndrome. $J$. Pediatr. 107:694-701.

66. Seyberth, H.W., S.J. Koniger, W. Rascher, P.G. Kuhl, and H. Schweer 1987. Role of prostaglandins in hyperprostaglandin E syndrome and in selected renal tubular disorders. Pediatr. Nephrol. 1:491-497.

67. Camras, C.B., R.A. Schumer, A. Marsk, J.S. Lustgarten, J.B. Serle, L.Z Bito, and S.M. Podos. 1992. Intraocular pressure reduction with PhXA34, a new prostaglandin analogue, in patients with ocular hypertension. Arch. Ophthalmol. 110:1733-1738.

68. Wolfson, B., S. Pickett, N.E. Scott, J.B. DeKernion, and J. Rajfer. 1993 Intraurethral prostaglandin E-2 cream: a possible alternative treatment for erectile dysfunction. Urology. 42:73-75.

69. Karim, A., L.F. Rozek, M.E. Smith, and K.G. Kowalski. 1989. Effects of food and antacid on oral absorption of misoprostol, a synthetic prostaglandin E1 analog. J. Clin. Pharmacol. 29:439-443.

70. Hesse, W.H., G. Rudofsky, and B.A. Peskar. 1991. Metabolism of intravenously administered prostaglandin E1 in patients with peripheral arterial occlusive disease. Klin. Wochenschr. 103:554-557.

71. Cawello, W., H. Schweer, R. Muller, R. Bonn, and H.W. Seyberth. 1994 Metabolism and pharmacokinetics of prostaglandin E1 administered by intravenous infusion in human subjects. Eur. J. Clin. Pharmacol. 46:275-277. 